\title{
Corrigendum
}

\section{Corrigendum to "Facile and Rapid Synthesis of Microwave Assisted Pd Nanoparticles as Non-Enzymatic Hydrogen Peroxide Sensor" [Int. J. Electrochem. Sci.,12 (2017) 762-769, doi: 10.20964/2017.01.26]}

Ozlem Sahin $^{1 *}$, Hilal Kivrak ${ }^{2}$, Arif Kivrak ${ }^{3}$, Hilal Çelik Kazıcl ${ }^{2}$, Orhan Alal $^{2}$, Dilan Atbas $^{2}$

${ }^{1}$ Chemical Engineering Department, Selcuk University, 42031, Konya Turkey

${ }^{2}$ Chemical Engineering Department, Yüzüncü Y1l University, 65081, Van Turkey

${ }^{3}$ Department of Chemistry, Yüzüncü Y1l University, 65081, Van Turkey

E-mail: hilalkivrak@gmail.com, hilalkivrak@yyu.edu.tr

Received: 3 January 2018 / Accepted: 4 January 2018 / Published: 5 January 2018

Due to publication errors, all of the Figures are missing in the published version. The Figure 1 is shown below:

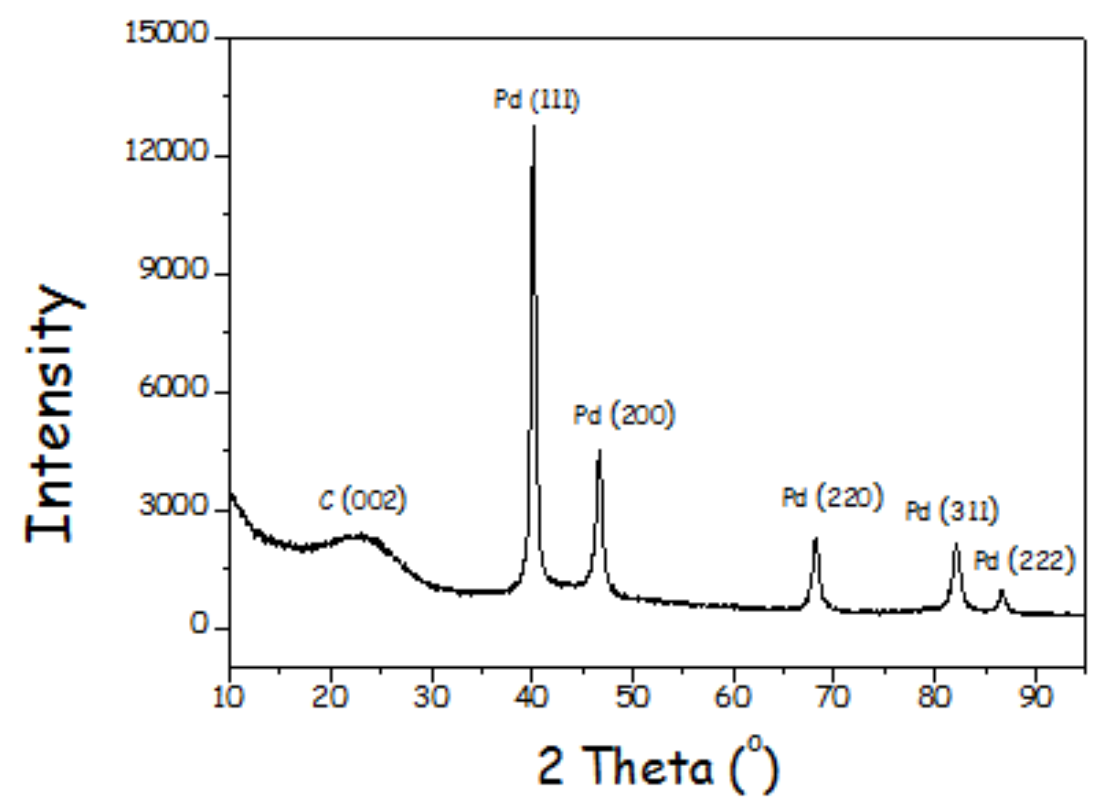

Figure 1. XRD patterns of M-Pd@C catalyst. 
Figure 2 is missed in the published version. The Figure 2 is shown below

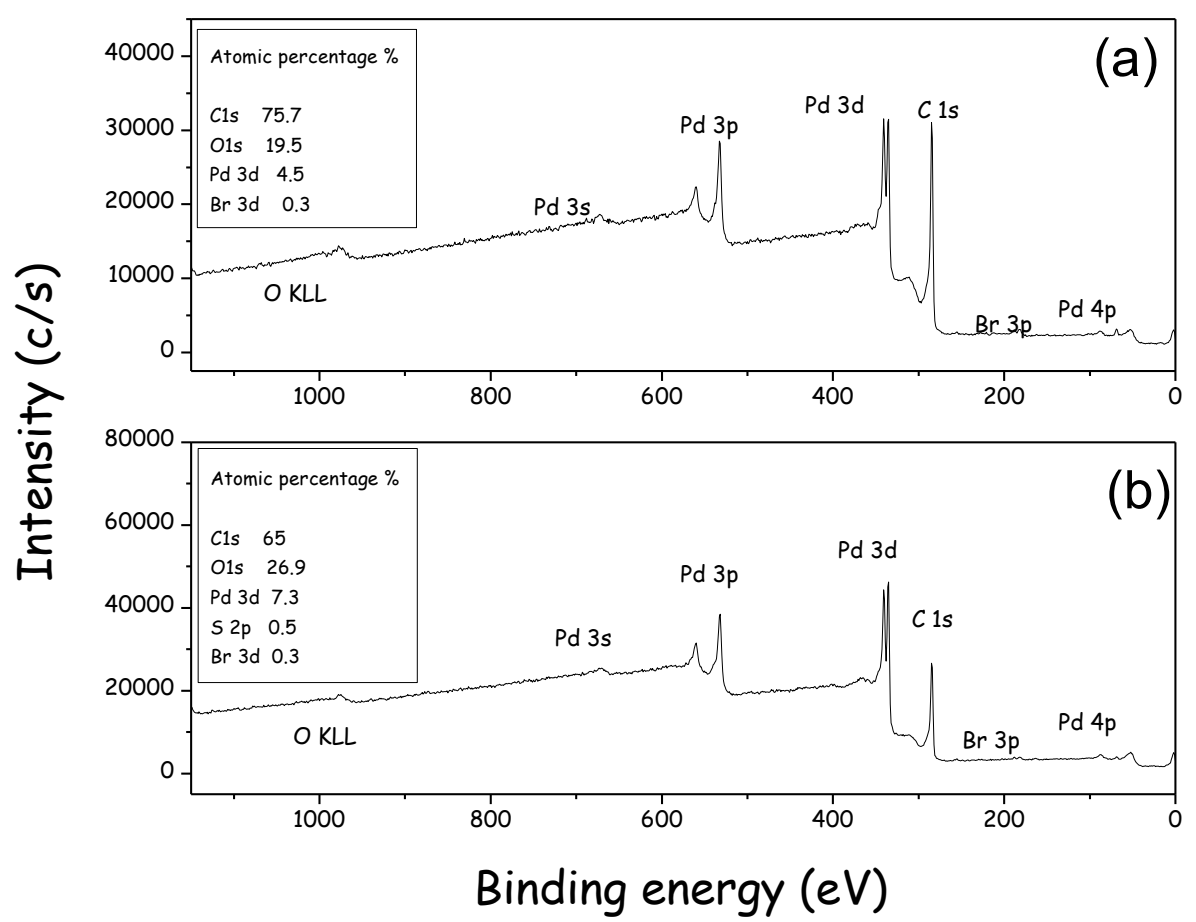

Figure 2. General spectrum of (a) M-Pd@C and (b) P-Pd@C catalysts.

Figure 3 is missed in the published version. The Figure 3 is shown below

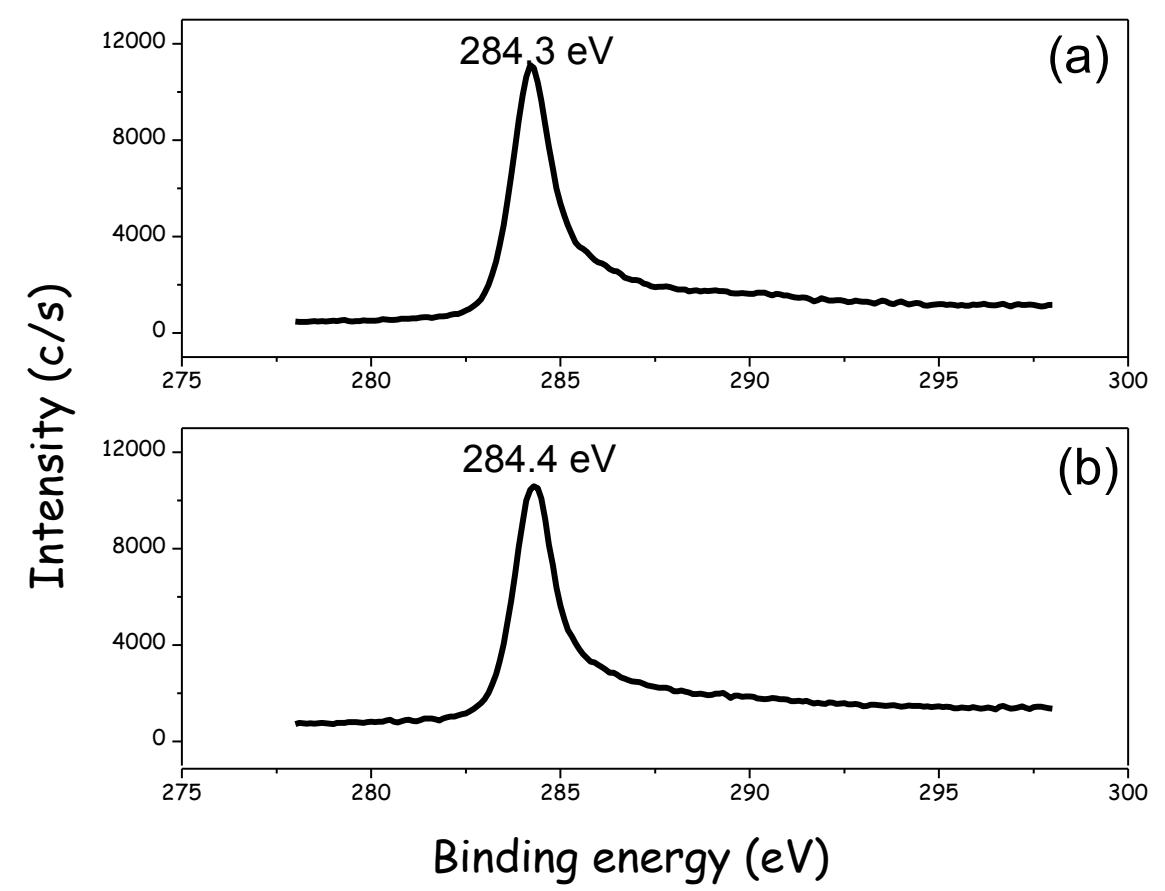

Figure 3. C 1s spectrum of (a) M-Pd@C and (b) P-Pd@C catalysts. 
Figure 4 is missed in the published version. The Figure 4 is shown below

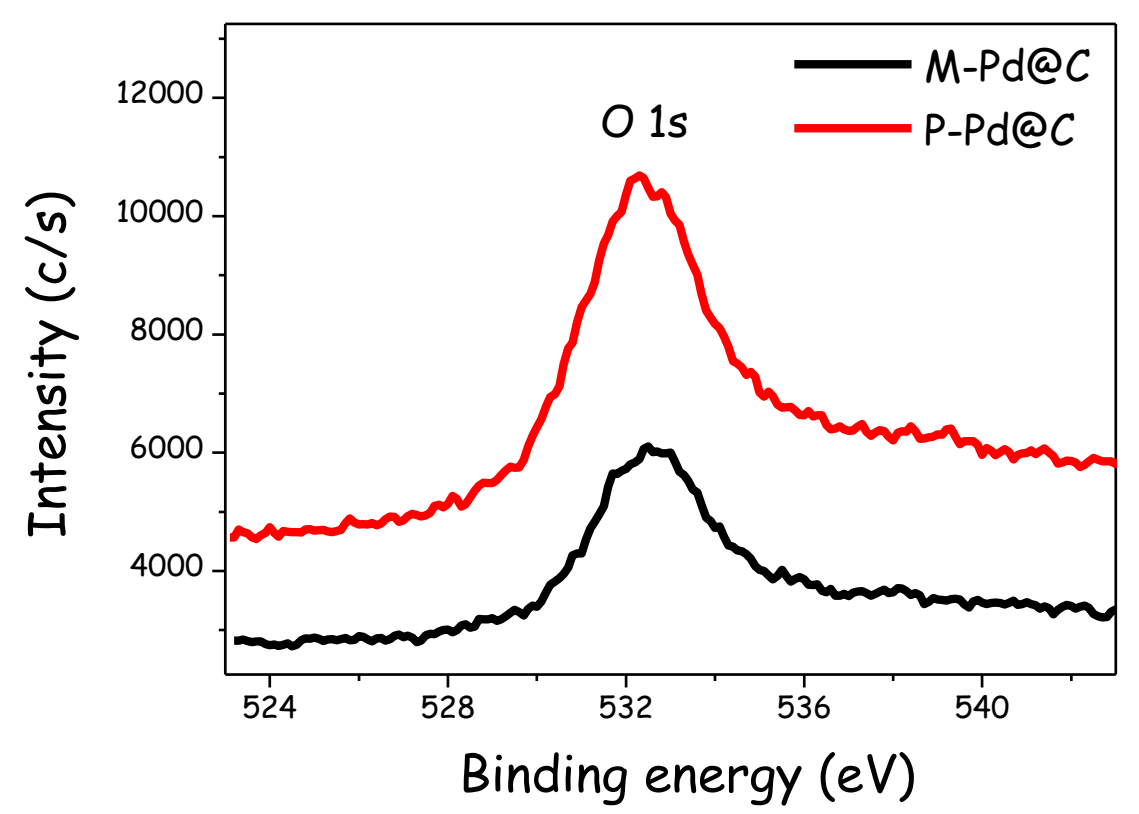

Figure 4. O1s spectrum of M-Pd@C and P-Pd@C catalysts.

Figure 5 is missed in the published version. The Figure 5 is shown below

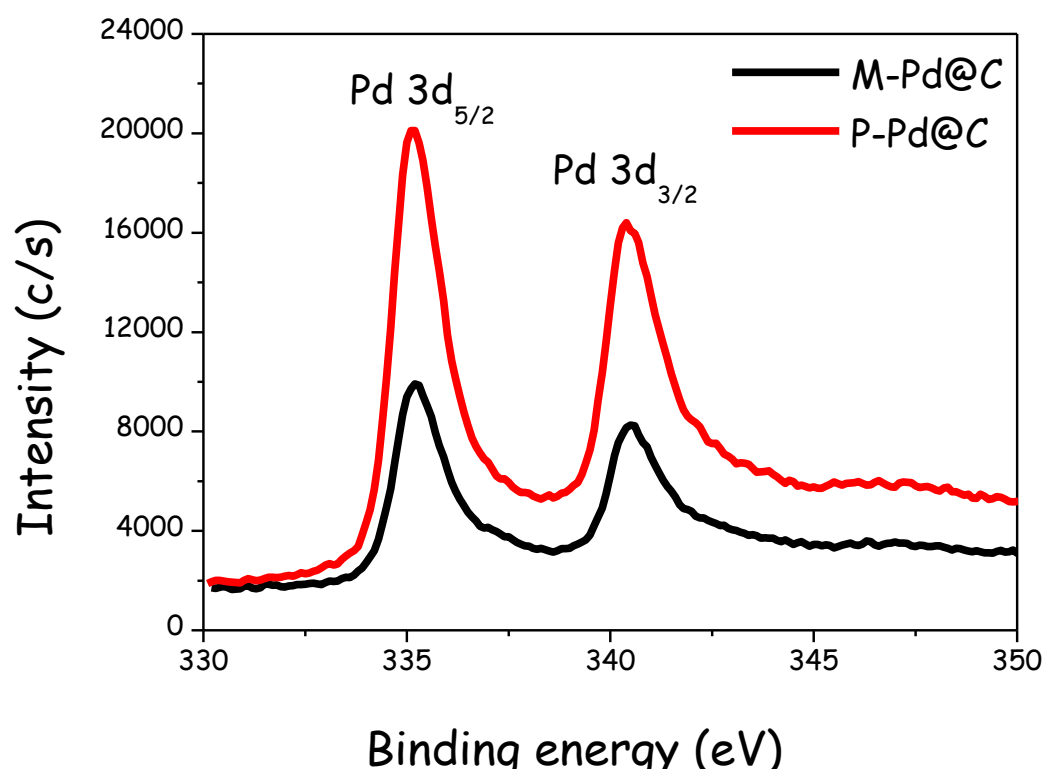

Figure 5. Pd 3d spectrum of M-Pd@C and P-Pd@C catalysts. 
Figure 6 is missed in the published version. The Figure 6 is shown below:
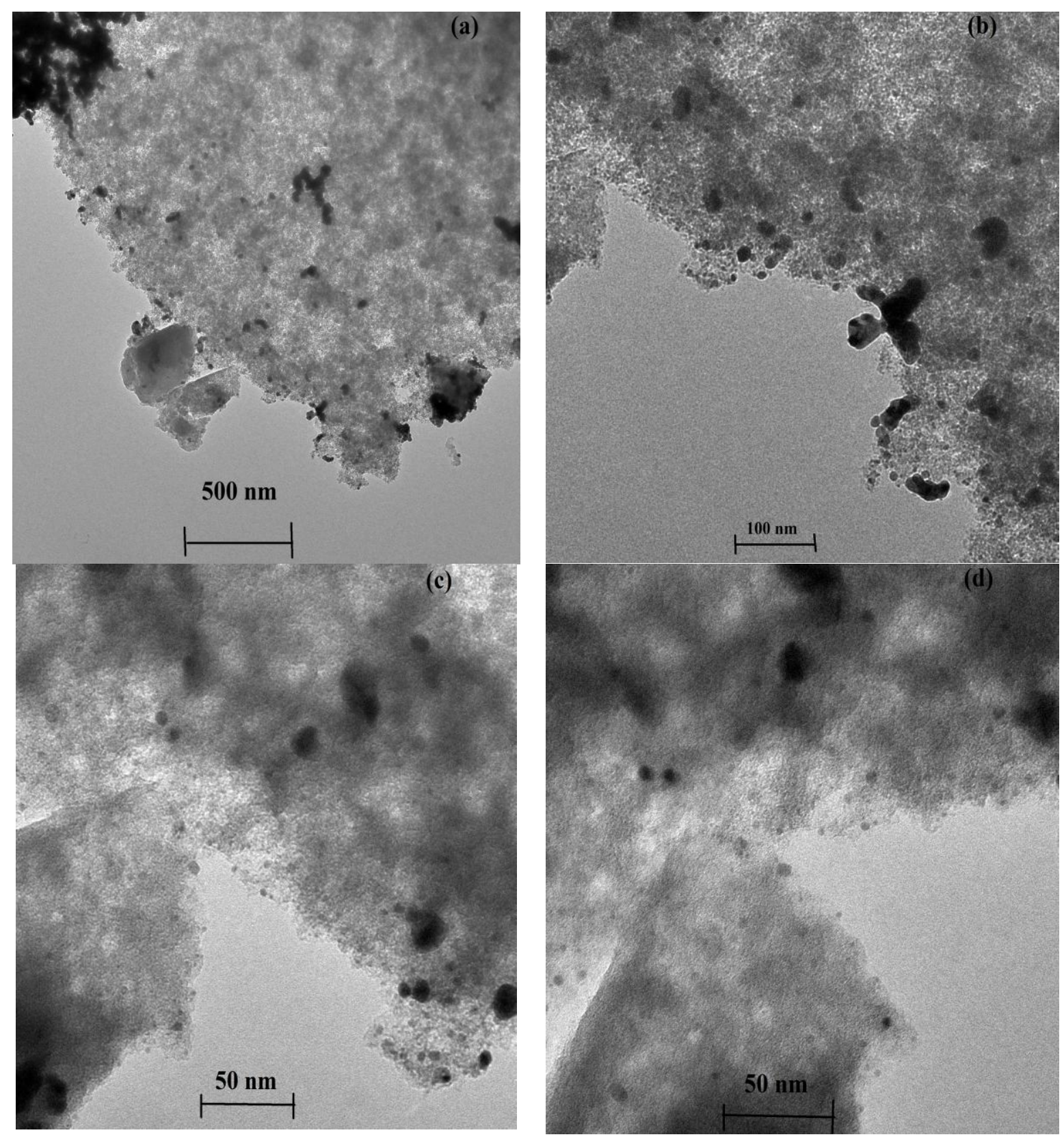

Figure 6. High and low resolution TEM images of M-Pd@C catalyst. 
Figure 7 is missed in the published version. The Figure 7 is shown below
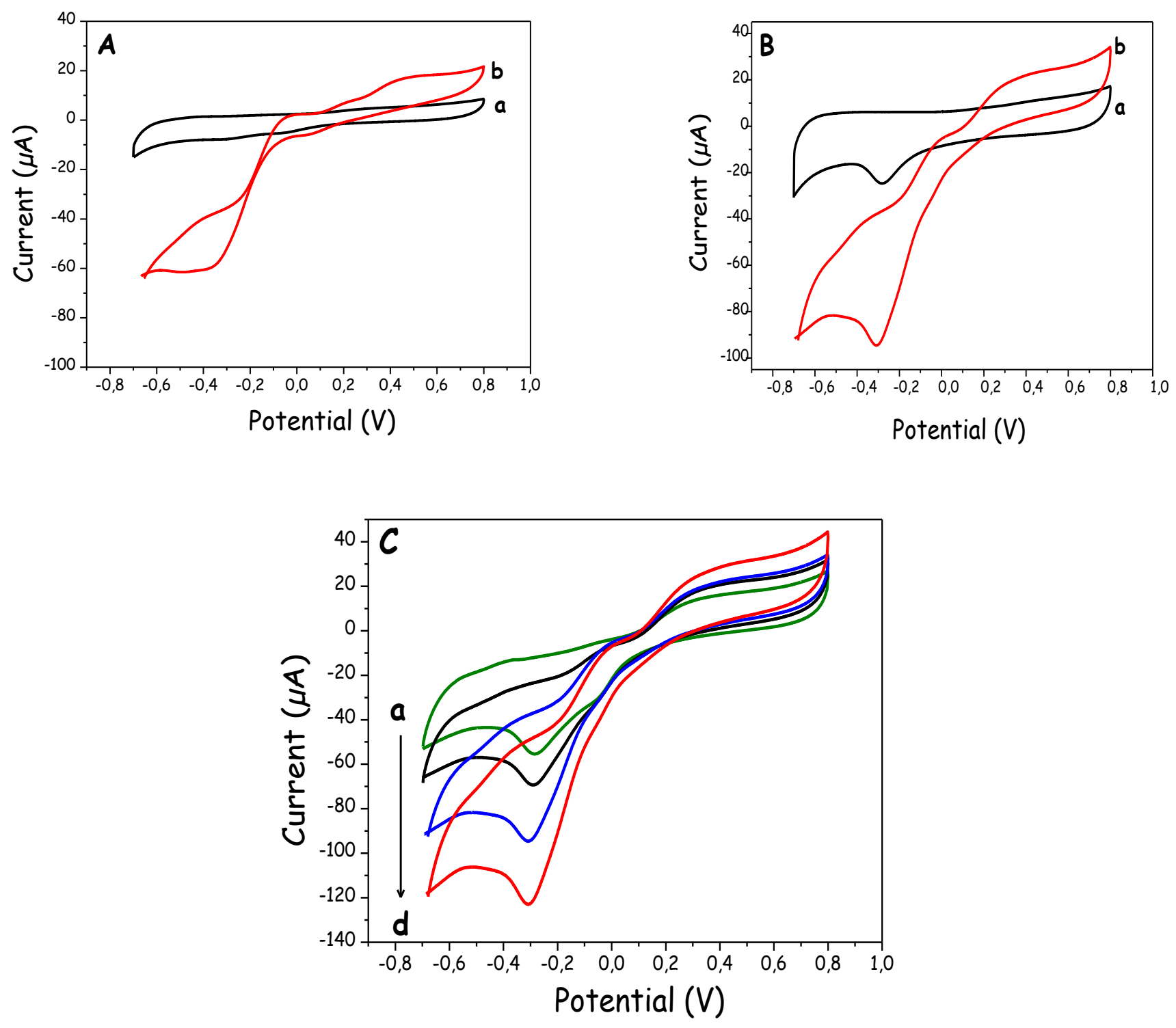

Figure 7. Cyclic voltammograms obtained at P-Pd@C (A) and M-Pd@C (B) modified electrodes in the absence (a) and presence (b) of $5 \mathrm{mM} \mathrm{H}_{2} \mathrm{O}_{2}$. Cyclic voltammograms obtained at M-Pd@C (C) modified electrode in the presence of $1.0 \mathrm{mM}$ (a), $2.5 \mathrm{mM}(\mathrm{b}), 5.0 \mathrm{mM}$ (c), and $10.0 \mathrm{mM}$ (d) $\mathrm{H}_{2} \mathrm{O}_{2}$ in $\mathrm{N}_{2}$ saturated $0.1 \mathrm{M}$ phosphate buffer solution at the scan rate of $50 \mathrm{mV} \mathrm{s}-1$. 
Figure 8 is missed in the published version. The Figure 8 is shown below:

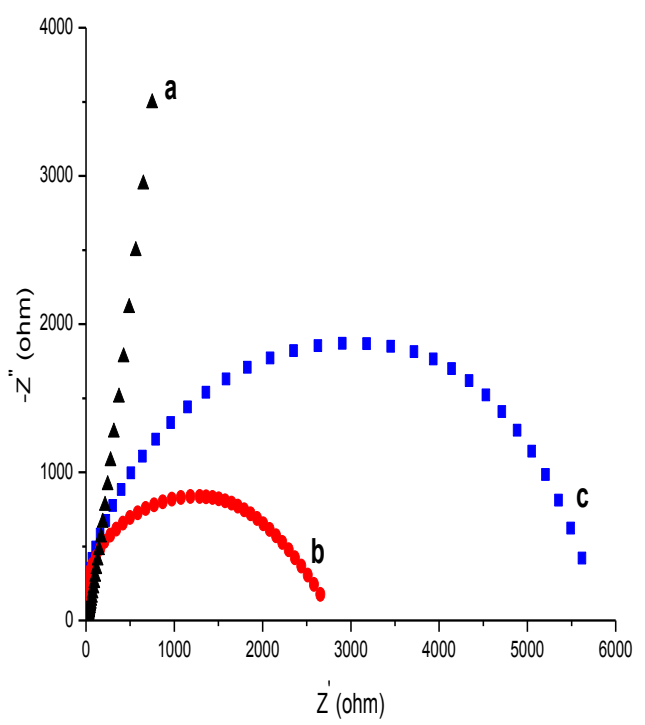

Figure 8. . EIS obtained at (a) bare, (b) $\mathrm{M}-\mathrm{Pd} / \mathrm{C}$ and (c) $\mathrm{P}-\mathrm{Pd} / \mathrm{C}$ glassy carbon electrodes in $\mathrm{N}_{2}$ saturated $0.1 \mathrm{M}$ phosphate buffer solution.

Figure 9 is missed in the published version. The Figure 9 is shown below:

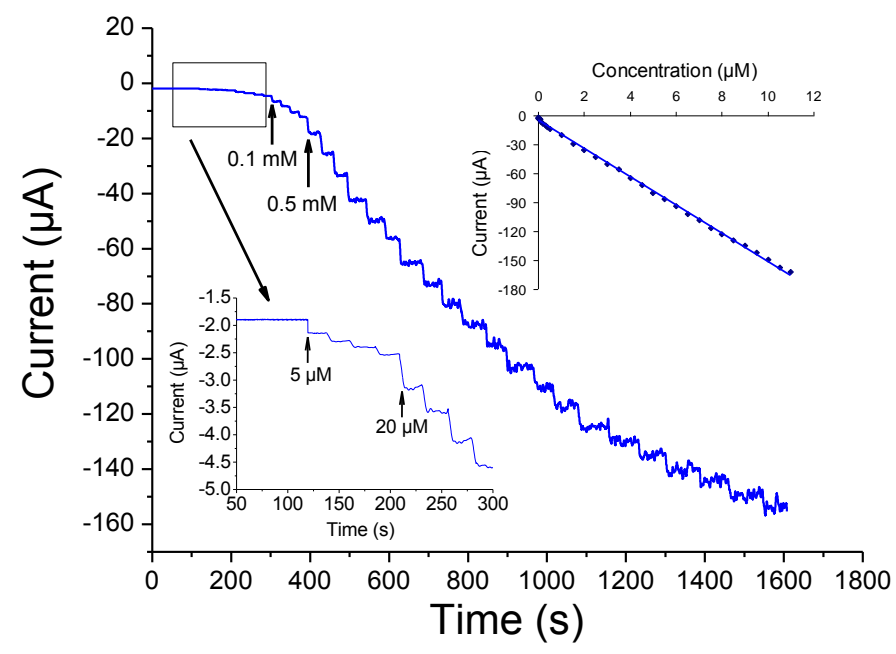

Figure 9. Amperometric response of M-Pd@C modified electrode for detection of $\mathrm{H}_{2} \mathrm{O}_{2}$ at $-0.3 \mathrm{~V}$ versus $\mathrm{Ag} / \mathrm{AgCl}$ in a stirred $0.1 \mathrm{M}$ phosphate buffer solution, $\mathrm{pH}$ 7.5. The upper right inset shows the calibration curve of M-Pd@C modified electrode for $\mathrm{H}_{2} \mathrm{O}_{2}$ concentration; the lower left inset zooms in the amperometric responses of $5 \mu \mathrm{M}, 5 \mu \mathrm{M}, 5 \mu \mathrm{M}, 5 \mu \mathrm{M}, 20 \mu \mathrm{M}, 20 \mu \mathrm{M}, 20$ $\mu \mathrm{M}, 20 \mu \mathrm{M} \mathrm{H}_{2} \mathrm{O}_{2}$ additions. 
Figure 10 is missed in the published version. The Figure 10 is shown below:

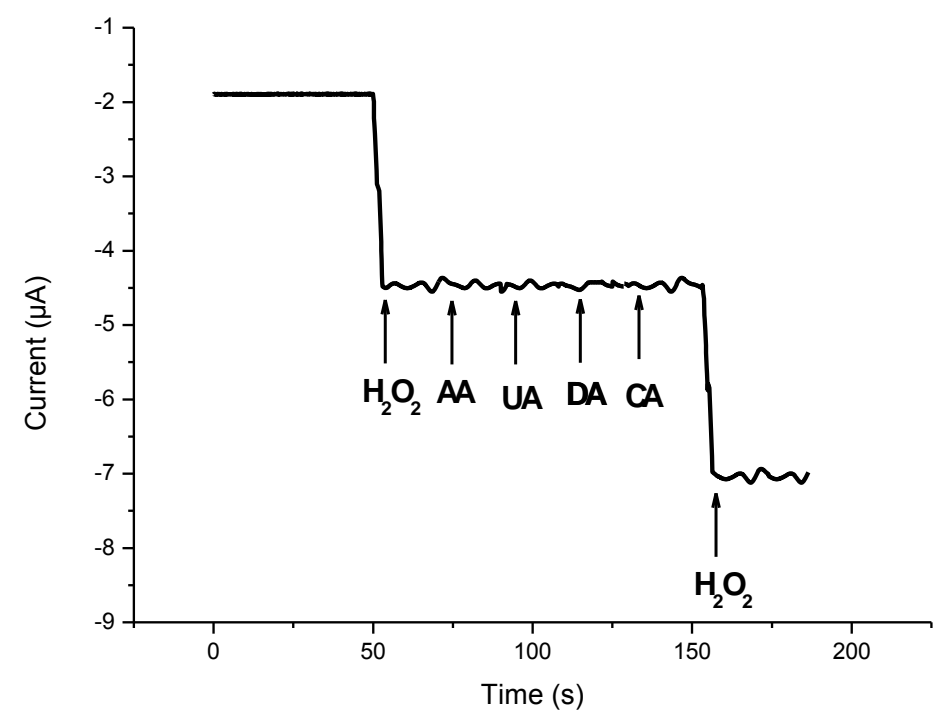

Figure 10. Amperometric response of $\mathrm{M}-\mathrm{Pd} / \mathrm{C}$ for successive additions of $0.1 \mathrm{mM} \mathrm{H}_{2} \mathrm{O}_{2}, \mathrm{AA}$, UA, DA, CA and $\mathrm{H}_{2} \mathrm{O}_{2}$ at $-0.3 \mathrm{~V}$ versus $\mathrm{Ag} / \mathrm{AgCl}$.

The publisher and authors would like to apologize for inconvenience caused.

(C) 2018 The Authors. Published by ESG (www.electrochemsci.org). This article is an open access article distributed under the terms and conditions of the Creative Commons Attribution license (http://creativecommons.org/licenses/by/4.0/). 